\title{
Commonwealth Local Government Forum Pacific Project
}

\author{
Commonwealth Journal of Local Governance \\ Issue 1: May 2008 \\ http://epress.lib.uts.edu.au/ojs/index.php/cjlg
}

\author{
Terry Parker \& Megan Praeger \\ CLGF Pacific Project
}

\section{Introduction}

The Commonwealth Local Government Forum (CLGF) Pacific Project works with local government and other stakeholders in nine Pacific Island countries - Cook Islands, Fiji Islands, Kiribati, Samoa, Papua New Guinea, Solomon Islands, Tonga, Tuvalu and Vanuatu. It seeks to strengthen local democracy and good governance, and to help local governments deal with the increasing challenges of service delivery and urban management in the unique Pacific environment.

Human settlement patterns in the region are changing rapidly. The Pacific has traditionally been a rural agricultural/subsistence society, but this is no longer the case. The accelerated pace of urbanisation has impacted significantly on Pacific nations and in the very near future the majority of Pacific Islanders will be found in urban areas. Already over 50\% of Fiji's population are urban dwellers. Rapid urbanisation brings with it unique challenges and opportunities. Local governments are at the forefront of this phenomenon, with the responsibility to manage urban development and the transition from rural areas to cities and towns. Their success or failure to manage urbanisation and provide the required levels of physical and social infrastructure will affect many lives in a new urban Pacific.

The project now has three components - the main Pacific Regional Project and two country-specific programmes: the Honiara City Council Institutional Capacity Building Project and the Commonwealth Local Government Good Practice Scheme in Papua New Guinea. 


\section{Background}

The project was initiated at a roundtable meeting held in 1997 in Port Moresby, convened by CLGF and hosted by the Papua New Guinea Minister for Inter-Government Relations. Initial financial support was received from the European Union and the New Zealand Agency for International Development (NZAID), and an office and resource centre was established in Suva, Fiji Islands in 2000. Building on this early work, in late 2004 CLGF and the Commonwealth Secretariat, together with the Government of Fiji, co-sponsored a Regional Symposium on Local Governance in the Pacific, held in Suva. This event, the first of its type to focus solely on local government, was attended by 90 representatives of 14 Pacific countries and development partners.

Emerging from the symposium was a proposal for a greatly expanded fiveyear regional local government capacity building project with the goal to improve quality of life for communities in the Pacific region through strengthened local democracy and good governance.

In 2005 NZAID agreed to support this scaled-up project. The Australian Agency for International Development (AusAID) also became a project partner, and in addition funded a series of CLGF Good Practice Scheme council partnerships between Australia and PNG. This led in 2007 to the establishment of a sub-office in Port Moresby. The regional office has steadily expanded and now works closely with a growing network of local government and development partners across the region to share information, ideas and good practice. A Technical Advisory Panel (TAP) comprising representatives of participating countries and partner agencies provides policy guidance and direction to the project.

In parallel with the establishment of the regional project, and at the request of the government of the Solomon Islands, in 2004 CLGF began working with Honiara City Council on a post-conflict institutional rebuilding and service delivery improvement project. The goal is to bring about sustainable improvements in quality of life for all citizens of the City of Honiara through sound city management, improved local services, planned urban development and good governance.

\section{CLGF Pacific Regional Project}

The overall regional project has activities in each of the nine participating countries. Key components are:

- Strengthening regional networks and cooperation between local government practitioners

- Enhancing training and capacity building opportunities for local government 
- Institutional strengthening programmes and activities that demonstrate fundamental values such as a human rights-based approach and mainstreaming of the tenets of good urban governance

- Regional exchange of policy and good practice, and technical cooperation.

The project is based on six key objectives:

1 Encourage appropriate, participatory, representative and responsive local government in the Pacific Region. Making sure that stakeholders and communities are empowered to engage in the processes of local governance. Effective engagement requires a combination of awareness, education, information dissemination, advocacy and consultation at all levels. Creation of sound legislative frameworks to ensure an enabling environment is also essential.

2 Ensure effective intergovernmental relations and central government support to local government. To create stronger partnerships and collaboration between the different levels of government - an important ingredient for better local governance and councils' service delivery in the Pacific. The project facilitates closer working relationships between national, local and traditional leaders, and civil society, through creating safe spaces for dialogue.

3 Enhance international and regional cooperation to promote effective local governance. Improving collaboration between international and regional agencies to address local governance issues by initiating and sustaining partnerships to promote good and effective local governance. The important role of local government associations in advocacy, coordination and capacity building is also a focus area of the project.

4 Build capacity of local government institutions and structures to respond to rapid urbanisation, deliver better services and hence provide an enabling environment for economic and social development. Building the capacity of those who are responsible for local government as well as their community and other stakeholders.

5 Promote effective management of urbanisation and good local governance. Regional and national initiatives designed to address the impacts of rapid urbanisation in the region, and also to promote good local governance in Fiji through awareness programmes, monitoring, workshops, information sharing and public relations programmes.

6 Ensure recommendations and outcomes of the Regional Symposium are implemented and monitored, and adequate capacity exists with $C L G F$ to manage the project implementation. Managing in the best interests of the project through effective project governance, management, administration and monitoring and evaluation, and ensuring that activities fit within the framework established by the 2004 Regional Symposium. 
Over 100 separate regional and country-specific activities are included in the workplan to meet these objectives. Examples include:

- Research on the state of local governance in the Pacific and the interface between traditional structures and local government

- Regional training of trainer programmes for Local Elected Leadership development and financial management, and national adaptation/roll out in all nine countries

- Training on leadership and management for city and town managers

- The Fiji Good Local Governance Campaign

- Voter education and awareness of local government

- Support for local government associations

- Promoting the role of women in local government

- Corporate planning, organisational reform and performance measurement

- Dialogues on appropriate local government systems, intergovernmental relations and relations with traditional leaders and civil society

- Regional activities under the Pacific Plan, particularly the Pacific Urban Agenda

- Establishment of a Capital Cities network

- Exchange programmes for local government practitioners and with Australia and New Zealand.

In addition to funding from NZAID and AusAID, the project is also supported by the Commonwealth Secretariat (which has financed the position of Regional Adviser), United Nations agencies, the University of the South Pacific (Pacific Institute of Advanced Studies in Development and Governance), the Pacific Islands Forum Secretariat, Local Government New Zealand, Local Government Managers Australia and others. It is firmly based on this network of relationships, involving a variety of regional partners with shared values and beliefs in the institution of local government and the desire to see it improved in the Pacific Region. 


\section{Box 1}

\section{Fiji Good Local Governance Campaign}

The Fiji Good Local Governance Campaign is a key activity supported by the CLGF Pacific Project designed to promote effective management of urbanization and good local governance in the Fiji context. Its goal is to improve local level governance as a means for more sustainable and inclusive urban development and management that leads to efficient and effective service delivery'. Key objectives are:

1. Raised awareness and advocacy for good local governance concepts, initiatives and activities

2. Strengthened partnerships at all levels for increased integration and coordination of good local governance initiatives and activities

3. Enhanced capacity of central government to promote good local governance and facilitate effective decentralisation for sustainable urban development

4. Enhanced capacity of municipal councils to practice good local governance and effectively manage decentralisation for sustainable urban development

The Campaign responds to needs identified in Fiji's Urban Policy Action Plan (UPAP) for local government capacity building to ensure sustainable urban development and address urban poverty. In doing so, it also meets the objectives of the Pacific Urban Agenda (an outcome of the Pacific Plan) to implement initiatives and build capacity to address priority urban planning and management challenges in Pacific Island Countries.

The strategic approach for the Campaign is broadly derived from UNHABITAT's Global Campaign on Urban Governance, adapted to respond to local needs, priorities, realities and activities. It has its own core programme of activities and also plays a coordinating role in the implementation of activities more broadly identified for Fiji under the CLGF Pacific Project workplan.

Core activities primarily focus on advocacy and knowledge management such as the development of awareness materials on the role of local government; public relations programmes including the 2007 Pacific Urban Art Competition; the development of an urban governance index; documentation of best practice cases through a film documentary (to be completed in September 2008); and support for increased participation of women in local government. Other activities coordinated by the Campaign include training on Local Elected Leadership (LEL), financial management and strategic planning.

The Campaign places a high priority on monitoring and evaluation of its activities and is piloting the 'Most Significant Change' (MSC) story collection technique to measure outcomes and in particular the impact of its training programmes. MSC documentation has shown that there is already 
a positive shift in thinking occurring and this is gradually translating into practical projects (see Box 2).

The Campaign is implemented by the Fiji Department of Local Government within the Ministry of Local Government, Urban Development and Housing. In the initial pilot phase (April 2005 -November 2007), a full-time coordinator was appointed to establish the Campaign and manage the dayto-day coordination of activities. From 2008 the focus will be on integrating this role into the core responsibilities of departmental staff and strengthening the partnership with the Fiji Local Government Association within the broader framework of the CLGF Pacific Project. Other key partners include UN agencies, the University of the South Pacific and civil society organizations. A National Steering Group of partners meets periodically to exchange information and provide guidance

\section{Box 2}

\section{Excerpts from Most Significant Stories about Local Elected Leadership Training}

[Before] Councillors did not understand the meaning of 'good governance' and how it applied to the decision-making process of the Council...[After] now Councillors understand the importance of ensuring the active and constructive participation of community stakeholders in the decision making process and this has greatly influenced the process undertaken to draw up a master plan for the town (Sigatoka)...'

[Before] The Council did not involve stakeholders in solving community problems...[After] now the Council seeks stakeholders involvement in problem solving such as crime prevention, anti-littering and control/supervision of illegal activities creating more community accountability for the outcomes.'

[Before] Our views were very limited and focused on local domestic issues...[After] now our views are broader in focus in terms of identifying international and regional impacts on local decision-making...'

Source: Excerpts from story collection on the LEL Decision-Making Competency

[Before] Council would inform citizens about increases in service fees but would always come up against resistance...[After] now the Council consults (rather than just informs) citizens before fees are increased and provides proper justification on a cost versus efficiency platform leading to more acceptance and ownership...'

[Before] The Council did not realise the roles NGOs can play in raising awareness about council decisions and activities...[After] since the workshop the Council has engaged with FemLINKPACIFIC to raise awareness through community radio about rate collections, clean-up programmes and other activities in the town. The Council has seen the 
positive response from community members and will continue to pursue other partnerships with local NGOs...'

Source: Excerpts from story collection on the LEL Enabling Competency

\section{Honiara City Council Institutional Capacity Building Project}

This project represents a significant regional technical partnership to support Honiara City Council and its stakeholders rebuild the institutional and service delivery capacity of the council following several years of national instability. The council operates within a changing and complex environment, characterised by amongst other things rapid urbanisation and high expectations but inadequate resources.

There are five key objectives:

1. Strengthened management capacity and processes. Including a restructured organisation, a new management team and counterparts, introduction of new rating systems and improvements to the council's revenue base, plus training and skills improvement.

2. Improved quality and delivery of essential services. Activities comprise upgrading office and depot facilities, improvements in refuse collection and disposal, upgrading central markets, roadworks and law enforcement.

3. Coordinated and well-planned urban development. This includes an enhanced zoning, development and building control framework, including a new local planning scheme and urban development strategy.

4. Promotion of good governance and local democracy. To be achieved through legislative review, orientation and leadership development for councillors, improved community consultation and engagement, and corporate planning.

5. Management of the Project effectively and in the City's best interests. Effective management by CLGF and support by partners.

The project is being implemented jointly by Honiara City Council and CLGF. The national Ministry of Home Affairs also supports project management and provides appropriate oversight. Other key partners are Local Government New Zealand (until recently principally through Kapiti Coast District Council) and Maryborough City Council in Queensland, Australia. The project is largely funded by NZAID. 


\section{Commonwealth Local Government Good Practice Scheme in Papua New Guinea}

The Commonwealth Local Government Good Practice Scheme (CLGGPS) was launched in 1998 and is designed to support projects based on the exchange of good practice and skills between local government practitioners. The aim is to use council partnerships to promote effective, responsive and accountable delivery of local authority services, particularly to poor and disadvantaged communities, identifying examples of good practice for application elsewhere.

The CLGGPS in Papua New Guinea began in 2000 with support from AusAID and addresses the challenges and realities being faced by urban local level governments in a rapidly changing environment. It seeks to build capacity within and amongst councils to improve the management and delivery of services to communities. The scheme has three key elements:

1. Council to Council partnerships, which currently include:

- Mt Hagen City/Orange City - development of a city plan, refuse collection and disposal plan, and women's empowerment/ economic development project.

- National Capital District Commission (Port Moresby)/Townsville City - improvement of regulatory services, property rating and information technology.

- Lae City/Cairns City - development of an integrated waste management strategy for the City of Lae.

- Alotau/Sunshine Coast - enhanced management of solid waste collection and disposal, improved billing system and new information technology.

2. Capacity building for the Papua New Guinea Urban Local Level Government Association (PNGULLGA). This follows assistance from the New South Wales Local Government and Shires Association for the development of a corporate plan for the Association.

3. Disseminating the outcomes and learning from the partnership projects to other local government stakeholders in PNG and beyond through information sharing and training seminars.

A further stage of the scheme is now being initiated, including at least three new partnerships for Goroka, Madang and Kokopo with councils in Australia. 


\section{Conclusion}

All three elements of the Pacific Project are now entering a consolidation phase. Although certainly not without its challenges, notably coordination within countries, responding to changing local priorities and unexpected circumstances, and ensuring adequate reporting and information dissemination, the project continues to register many successes. These are derived to a large extent from its partnership philosophy and approach: assembling a network of local governments, ministries and development partners across the region who are willing to forge close working relationships, share information and ideas, and invest the time, energy and resources necessary for a concerted capacity building effort.

The value of this approach is demonstrated very clearly by the project's 'flagship' component, the Local Elected Leadership (LEL) training programme carried out in conjunction with UN-HABITAT. So far, around 500 local leaders in the region have experienced this programme. In many cases, this is the first time they have been exposed to such training and it is undoubtedly contributing to an increase in leadership knowledge and skills across the region, enabling local governments to better respond to the many challenges they face. Positive changes in attitude have been observed as a result of LEL training (see Box 2), and the innovative activities now emerging indicate that this is being translated into practical development outcomes. 